\title{
Edukasi Kesehatan dalam Upaya Pencegahan Penyakit Diabetes di Era Pandemi COVID-19
}

\author{
Cecilia Widijati Imam¹, Rea Ariyanti², Vincensia Dea Prasetya Putri ${ }^{3}$ \\ STIKes Panti Waluya Malang, Jln. Yulius Usman no.62 Kota Malang, Jawa Timur \\ Email: cecilia.dewanta@gmail.com ${ }^{1 *}$
}

\begin{abstract}
ABSTRAK
Kegiatan Program Kemitraan Masyarakat "Edukasi Kesehatan dalam Upaya Pencegahan Penyakit Diabetes di era pandemi COVID-19" dengan pengkajian awal terhadap keadaan di lapangan melalui kader dan warga. Pengkajian awal di dapatkan permasalahan bahwa masih kurangnya pemahaman kader dan warga terkait penyakit tidak menular dan belum optimalnya upaya pencegahan penyakit diabetesMayoritas PTM terjadi di negara berpendapatan rendah dan menengah. Meningkatnya kasus Penyakit Tidak Menular (PTM) secara signifikan akan menambah beban masyarakat dan pemerintah, karena penanganannya membutuhkan waktu yang tidak sebentar, biaya yang besar dan teknologi tinggi Faktor risiko PTM berkaitan erat dengan pola hidup. Empat faktor utama penyebab PTM adalah makanan tidak sehat, kebiasaan merokok, penggunaan alkohol, gaya hidup tidak sehat seperti aktivitas fisik yang kurang. Selain itu, tingkat kepedulian masyarakat akan kesehatan yang masih rendah juga menjadi penyebab tingginya kejadian PTM Kegiatan pengabdian kepada masyarakat ini diawali dengan melakukan sosialisasi kepada kader dan warga terkait pengertian penyakit tidak menular dan upaya pencegahan diabetes dengan menggunakan media pembelajaran berupa video. Dengan adanya edukasi mengenai diabetes ini para kader dan warga dapat melakukan upaya pencegahan penyakit diabetes dengan optimal.
\end{abstract}

Kata kunci: Edukasi, Penyakit Tidak Menular, Diabetes

\begin{abstract}
Community Partnership Program Activity "Health Education in Efforts to Prevent Diabetes in the COVID 19 Pandemic Era" with an initial assessment of the situation in the field through cadres and residents. The initial assessment found that there was still a lack of understanding by cadres and residents regarding noncommunicable diseases and that efforts to prevent Diabetes were not yet optimal. The majority of PTM occurs in low and middle-income countries. The increase in Non-Communicable Diseases (PTM) cases will significantly increase the burden on society and the government because handling takes a long time, costs a lot, and is high technology. PTM risk factors are closely related to lifestyle. The four main factors causing PTM are unhealthy food, smoking habits, alcohol use, unhealthy lifestyles such as inadequate physical activity. In addition, the low level of public awareness of health is also the cause of the high incidence of PTM. This community service activity begins with disseminating information to cadres and residents regarding the understanding of non-communicable diseases and efforts to prevent Diabetes by using learning media in the form of videos. With this education about Diabetes, cadres and residents can carry out preventive efforts to Prevent Diabetes optimally.
\end{abstract}

Keywords: Education, Non-Communicable Diseases, Diabetes

\section{PENDAHULUAN}

Penyakit tidak menular (PTM) adalah penyakit atau kondisi medis yang tidak dapat ditularkan dari satu individu ke individu lainnya atau dengan pengertian lain merupakan 
penyakit yang bukan disebabkan oleh proses infeksi (tidak infeksius). Secara signifikan meningkatnya kasus penyakit tidak menular dapat meningkatkan beban pemerintah dan masyarakat dengan penanganan yang memakan waktu cukup lama dan biaya tinggi.

Berdasarkan hasil Riskesdas dari tahun 2007, 2013 dan 2018 menunjukkan bahwa prevalensi PTM terus meningkat. Jenis PTM yang mengalami peningkatan prevalensi antara lain kanker, stroke, penyakit ginjal kronis, diabetes melitus, dan hipertensi (Cahyani et al., 2020). Pergeseran pola penyakit (transisi epidemiologi) dalam 30 tahun terakhir ini disebabkan karena perubahan gaya hidup (lifestyle) di masyarakat (Cahyani et al., 2020)

Faktor risiko PTM berkaitan erat dengan pola hidup. Empat faktor utama penyebab PTM adalah makanan tidak sehat, kebiasaan merokok, penggunaan alkohol, gaya hidup tidak sehat seperti aktivitas fisik yang kurang (Kemenkes.RI, 2016). Selain itu, tingkat kepedulian masyarakat akan kesehatan yang masih rendah juga menjadi penyebab tingginya kejadian PTM. Tekanan darah tinggi, obesitas, kadar gula tinggi dan kolesterol tinggi merupakan faktor risiko tinggi terkena penyakit tidak menular.

Meningkatnya kejadian PTM menambah beban penyakit di Indonesia. Beban yang dimaksud meliputi kerugian finansial, angka morbiditas atau keadaan sakit yang tinggi, dan mortalitas atau angka kematian yang tinggi (Rahmasari dkk., 2020). Menyikapi fenomena ini, pemerintah mencanangkan Gerakan Masyarakat Hidup Sehat (Germas) yang mengedepankan upaya promotif dan preventif (Rahmasari dkk., 2020). System Germas diimplementasikan dalam bentuk CERDIK: Cek kesehatan secara berkala, Enyahkan asap rokok, rajin beraktivitas fisik, diet yang sehat dan seimbang, istirahat yang cukup dan kelola stress (Kemenkes.RI, 2016).

Tindakan pencegahan yang dapat dilakukan yaitu cek kesehtaan secara rutin. Edukasi dengan mengajak kader kesehatan berperan sangat penting di masyarakat, mengingat penyakit diabetes ini sangat beresiko bagi masyarakat. Selain itu, diabetes Melitus merupakan penyakit kronis yang menurunkan kemampuan dari pasien, sehingga jika kader dilibatkan dalam system edukasi ini, masyarakat dapat membantu melakukan penatalaksanaan dm dan meningkatkan perilaku perawatan diri pada pasien saat kondisi pasien mulai memburuk (R et al., 2019).

Diabetes umumnya terjadi pada saat pola gaya hidup dan perilaku sudah modern dan mapan. Partisipasi keluarga, pasien dan masyarakat sangat dibutuhkan, dan di dampingi oleh tim kesehatan untuk menuju perilaku yang sehat. Untuk mencapai keberhasilan perubahan perilaku, dibutuhkan edukasi yang komprehensif dan upaya peningkatan motivasi (Sari dan Yamin, 2018). Edukasi merupakan salah satu proses berlangsung secara terus menerus, 
yang kemajuannya harus terus diamati (Sari dan Yamin, 2018). Tujuan pendidikan kesehatan pertama-tama untuk meningkatkan pengetahuan tentang DM. Meningkatnya pengetahuan dapat dilihat dengan perubahan gaya hidup dan sikap yang pada akhirnya membentuk perubahan perilaku pada masyarakat dan kualitas hidup pasien DM. Edukasi yang dilaksanakan pada kegiatan ini melibatkan masyarakat sekitar dan kader.

\section{METODE}

Pelaksanaan kegiatan pengabdian kepada masyarakat dilakukan di RT.15 Dusun persen, Kab. Banyuwangi yang berlangsung selama 2 kali pertemuan pada tanggal 23 dan 27 januari 2021 dan diikuti 25 orang. Karakteristik warga merupakan bapak ibu yang aktif dalam kegiatan. Metode yang akan dilaksanakan untuk kegiatan pengabdian masyarakat ini berupa penyuluhan dan diskusi interaktif yang dilakukan secara daring.

Metode pada kegiatan pengabdian kepada masyarakat ini dilakukan 3 tahap yaitu tahap persiapan, Tahap pelaksanaan dan tahap evalusai. Pada tahap persiapan tim pengabdi melakukan perijinan terkait kegiatan yang akan dilakukan, dan berdiskusi menentukan waktu pengabdian masyarakat. Pada tahap pelaksanaan dilakukan dengan memberikan edukasi kepada kader dan warga secara daring mengingat kondisi pandemi COVID-19, tentang pencegahan diabetes. Pada tahap evaluasi dilakukan untuk menilai pemahaman kader dan warga terhadap materi yang telah diberikan, sebelum pemberian materi terlebih dahulu akan diberikan pretest dan diberikan postest pada akhir kegiatan.

\section{HASIL, PEMBAHASAN, DAN DAMPAK}

Program kegiatan pada masyarakat dilaksanakan di RT.15 Dusun Persen, Kec. Tegaldlimo, Kab. Banyuwangi mendapatkan respon yang baik dari kader dan warga. Sasaran utama dari program ini adalah kader dan waraga di Dusun Persen. Pelaksanaan dilakukan sebanyak 2 kali secara daring dengan metode penyuluhan dan diskusi interaktif. Sebelum dilakukan edukasi kesehatan terlebih dahulu tim pengabdi melakukan pretest kepada kader dan warga terkait penyakit diabetes. Setelah diberikan materi sebanyak 2 kali peserta kembali diberikan posttest untuk mengukur tingkat pemahaman kader dan warga. Antusias yang ditunjukkan cukup tinggi melihat keaktifan pada saat penyuluhan dan diskusi. 


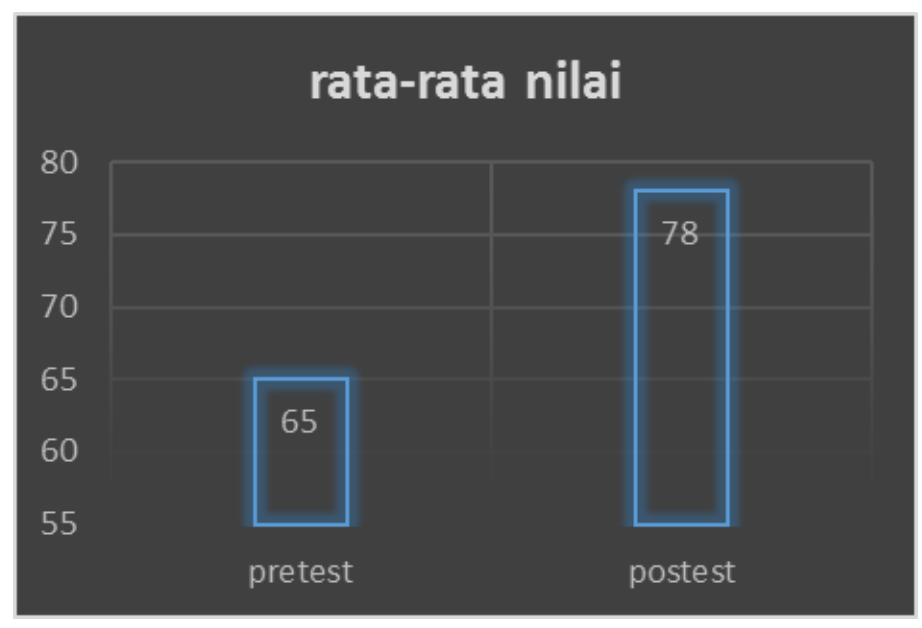

Gambar 1. Evaluasi nilai pretest dan postest

Hasil diatas merupakan hasil analisa data yang dilakukan terhadap nilai pretest dan postest peserta penyuluhan. Dapat diketahui bahwa telah terjadi peningkatan pemahaman terkait upaya pencegahan penyakit diabetes. Peningkatan pemahaman telah dibuktikan dengan nilai pretest dan posttest peserta. Rata-rata nilai sebelum dilakukan penyuluhan yaitu 65 , sedangkan rata-rata nilai setelah dilakukan dilakukan penyuluhan adalah 78 . Hal ini menunjukkan bahwa telah terjadi peningkatan pemahaman peserta antara sebelum dan sesudah dilakukannya penyuluhan.

Pelaksanaan penyuluhan dilakukan 2 (dua) kali pada tanggal 23 dan 27 januari 2021 dengan metode ceramah dan diskusi interaktif bersama kader dan warga RT.15 Dusun persen sejumlah 25 orang dengan materi penyuluhan penyakit tidak menular dan pencegahan penyakit diabetes. Materi yang diberikan yaitu tentang penyakit tidak menular mulai dari pengertian hingga factor risiko, materi diabetes dari pengertian hingga langkahlangkah pencegahan penyandang diabetes di masa pandemi COVID-19.

Meningkatnya kejadian PTM menambah beban penyakit di Indonesia. Beban yang dimaksud meliputi kerugian finansial, angka morbiditas atau keadaan sakit yang tinggi, dan mortalitas atau angka kematian yang tinggi (Rahmasari dkk., 2020). Menyikapi fenomena ini, pemerintah mencanangkan Gerakan Masyarakat Hidup Sehat (Germas) yang mengedepankan upaya promotif dan preventif (Rahmasari dkk., 2020). Program Germas diimplementasikan dalam bentuk CERDIK: Cek kesehatan secara berkala, Enyahkan asap rokok, rajin beraktivitas fisik, diet yang sehat dan seimbang, istirahat yang cukup dan kelola stress (Kemenkes.RI, 2016). Salah satu bentuk pencegahannya yakni dengan mengecek kesehatan secara berkala. 
Diabetes umumnya terjadi pada saat pola gaya hidup dan perilaku sudah modern dan mapan. Partisipasi keluarga, pasien dan masyarakat sangat dibutuhkan, dan di dampingi oleh tim kesehatan untuk menuju perilaku yang sehat.

\section{SIMPULAN}

Kesimpulan dari Kegiatan pengabdian kepada masyarakat yang dilakukan berjalan dengan lancar. Antusias kader dan warga sangat baik, aktif dan dapat bekerjasama dengan baik. Hasil dari kegiatan ini dilihat dari hasil pretest dan postest adalah pemahaman kader dan warga tentang penyakit tidak menular dan pencegahan diabetes dapat menigkat.

\section{DAFTAR PUSTAKA}

Cahyani, D. I., Kartasurya, M. I., \& Rahfiludin, M. Z. (2020). Gerakan Masyarakat Hidup Sehat dalam Perspektif Implementasi Kebijakan (Studi Kualitatif). Jurnal Kesehatan Masyarakat Indonesia, 15(1), 10. doi: 10.26714/jkmi.15.1.2020.10-18

Kemenkes.RI. (2016). Profil Penyakit Tidak Menular Tahun 2016. In Journal of Chemical Information and Modeling (Vol. 53, Issue 9).

Kementrian Kesehatan RI. (2020). nfodatin Tetap Produktif, Cegah, dan Atasi Diabetes Melitus 2020. In Pusat Data dan Informasi Kementrian Kesehatan RI (pp. 1-10).

Maharani Pulungan, U. Q. K. (2020). Pembentukan Pos Edukasi PTM (Penyakit Tidak Menular) di Puskesmas Cikulur. Ikraith Abdimas, 3(3), 91-96.

Purdiyani, F. (2016). Pemanfaatan Pos Pembinaan Terpadu Penyakit Tidak Menular (Posbindu Ptm) Oleh Wanita Lansia Dalam Rangka Mencegah Penyakit Tidak Menular Di Wilayah Kerja Puskesmas Cilongok 1. Jurnal Kesehatan Masyarakat (eJournal), 4(1), 470-480.

R, A. P., Nurdin, N., \& Saleh, U. (2019). Pendampingan Posyandu Lanjut Usia. Media Karya Kesehatan. 2(1), 74-84. doi : 10.24198/mkk.v2i1.19399

Rahmasari, F. V., Denny Anggoro P, Fadli Mahjud, \& Latifah Mutiara Haryanto. (2020). Gerakan Pemuda sebagai Basis Promotif dan Preventif Pra Lansia dan Lansia. Jurnal Pengabdian UntukMu NegeRI, 4(1), 10-16. doi: 10.37859/jpumri.v4i1.1346

Sari, C. W. M., \& Yamin, A. (2018). Edukasi Berbasis Masyarakat untuk Deteksi Dini Diabetes Melitus Tipe 2. Media Karya Kesehatan, 1(1), 29-38. doi: $\underline{10.24198 / \mathrm{mkk} . v 1 \mathrm{i} 1.17127}$

Soelistijo SA, Novida H, Rudijanot A, Suastika K, Manaf A, H Zufry. Konsensus pengelolaan dan pencegahan diabetes melitus tipe 2 di Indonesia. Jakarta: PB PERKENI; 2015. P13-14 